ПРОФЕСІЙНА КУЛЬТУРА МАЙБУТНІХ ФІЗИЧНИХ ТЕРАПЕВТІВ ТА ЕРГОТЕРАПЕВТІВ: СУТНІСНО-КОМПОНЕНТНИЙ АНАЛІЗ

\title{
PROFESSIONAL CULTURE OF FUTURE PHYSICAL THERAPISTS AND ERGOTHERAPISTS: ESSENTIAL-COMPONENT ANALYSIS
}

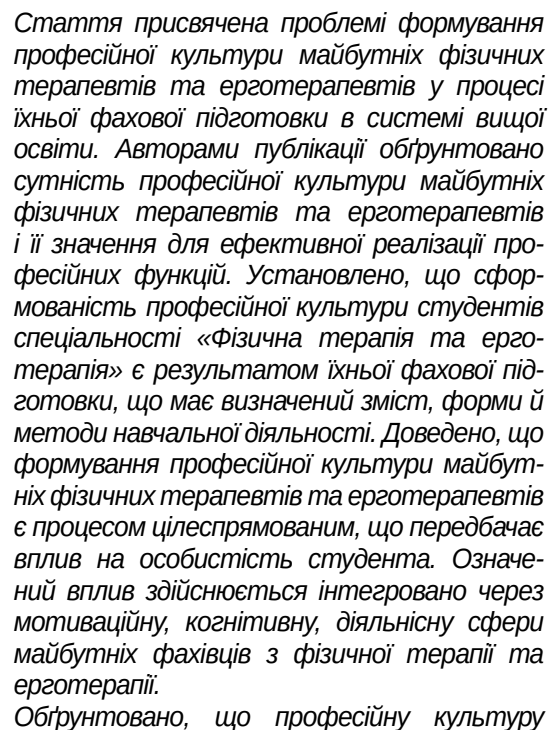
майбутніх фрахівців фрізичної терапії та ерготерапії можна розглядати як сукупність просресійних та особистісних иінностей студента, його спрямованості на майбутню просресію, фрахової компетентності (знання й уміння) і професійно значущих якостей, що комплексно забезпечують ефективне здійснення фрахової діяльності через реалізацію профресійних функцій.

Виокремлено структурні компоненти профресійної культури майбутніх фрізичних терапевтів та ерготерапевтів. До них зараховано ціннісно-мотиваційний, когнітивно-діяльнісний, особистісний та оцінювально-рефрлексивний. Проаналізовано зміст кожного компонента професійно культури. Ціннісно-мотиваційний компонент включає мотиви студентів до оволодіння професійною культурою, спрямованість на майбутню професію та їх цінності. Когнітивно-діяльнісний компонент охоплює систему фахових знань і вмінь для реалізації профресійних функцій. Особистісний компонент передбачає наявність профресійно значущих якостей як фрахівця. Рефлексивний компонент включає здатність до оцінювання й самооцінювання власної профресійної діяльності. Представлено взаємозв'язок між компонентами профресійної культури та їх вплив на ефрективну реалізацію професійної діяльності.

Ключові слова: фрізичний терапевт та ерготерапевт, професійна підготовка, про- фесійна культура, структурні компоненти професійної культури.

The article is devoted to the problem of formation of professional culture of future physical therapists and ergotherapists in the process of their professional training in the higher education system. The authors of the publication substantiate the essence of professional culture of future physical therapists and ergotherapists and its importance for the effective realization of professional functions. It is established that the formation of professional culture of students of the specialty "Physical therapy and ergotherapy" is the result of their professional training, which has a definite content, forms and methods of educational activity. It is proved that the formation of professional culture of future physical therapists and ergotherapists is a purposeful process that involves influencing a student's personality. The identified impact is implemented integrally through the motivational, cognitive, activity spheres of future specialists in physical therapy and ergotherapy.

It is substantiated that the professional culture of future specialists of physical therapy and ergotherapy can be considered as a set of professional and personal values of the student, his focus on the future profession, professional competences (knowledge and skills) and professionally important qualities that comprehensively ensure the effective implementation of professional functions.

The structural components of the professional culture of future physical therapists and ergotherapists have been distinguished. These include: value-motivational, cognitive-activity, personal and evaluative-reflexive component. The content of each component of professional culture is analyzed. The value-motivational component includes students' motives for mastering a professional culture, their focus on the future profession and their values. The cognitive-activity component encompasses a system of professional knowledge and skills for the exercise of professional functions. The personal component implies the presence of professionally significant qualities as a specialist. The reflective component includes the ability to evaluate and self-evaluate one's professional activity. The relationship between the components of professional culture and their influence on the effective realization of professional activity is presented.

Key words: physical therapist and ergotherapist, professional training, professional culture, structural components of professional culture.
Постановка проблеми в загальному вигляді. Інтеграція України в європейський простір змінює підходи суспільства до розуміння людини як найвищої цінності й визначення пріоритетних напрямів державної політики щодо створення умов для профрілактики, збереження та зміцнення ії здоров'я. Відповідно, з'явилася нагальна потреба у фрормуванні високопрофесійних фрахівців галузі
«Охорона здоров'я», зокрема фрізичних терапевтів та ерготерапевтів, які володіли б професійною культурою як запорукою успішності реалізації фахових фрункцій.

Аналіз останніх досліджень і публікацій. На сучасному етапі розвитку педагогічної науки накопичений значний досвід з вивчення проблеми фрормування професійної культури майбутніх фрахівців 
у процесі навчання у вищій школі, що представлений такими ученим, як С. Артюнов, І. Зарецька, І. Ісаєв, Є. Климов, Л. Коган, які розкривали сутність, складники й умови їі фрормування в студентів. Формування фрахівця з фрізичної культури, реабілітації терапії, ерготерапії досліджували Н. Бєлікова, Р. Карпюк, Є. Приступа, Л. Сущенко, О. Міхеєнко, Ю. Лянной та ін., які розглянули різні аспекти змісту, фрорм, методів профресійної підготовки таких фрахівців у процесі навчання їх у закладі вищої освіти.

Виділення не вирішених раніше частин загальної проблеми. Водночас теоретичний аналіз наукової літератури 3 означеної проблеми засвідчив, що фрормування професійної культури майбутніх фрізичних терапевтів та ерготерапевтів у процесі фрахової підготовки не було предметом окремого наукового дослідження, що зумовлює актуальність і доцільність його вивчення.

Мета статті - на основі структурно-змістового аналізу розкрити сутність поняття «профресійна культура майбутніх фрізичних терапевтів та ерготерапевтів» та обґрунтувати її компоненти, що забезпечують високий рівень професійної діяльності.

Виклад основного матеріалу. Вимоги до професійної діяльності фрізичних терапевтів та ерготерапевтів на сучасному етапі ресрормування українського суспільства підвищуються й перебувають не лише в діяльнісній, а й особистісній площині. Сучасний фахівець з фрізичної терапії та ерготерапії повинен бути конкурентоспроможним, що вимагає від нього інноваційного підходу до виконання професійних фрункцій; уміння працювати в міждисциплінарній команді для забезпечення якісного результату впливу на клієнтів; знань новітніх реабілітаційних технологій і здатності їх застосовувати в практичній діяльності з метою профрілактики та корекції рухових дій людей.

Готовність майбутнього фрахівця до якісної реалізації профресійної діяльності визначається сфрормованістю його профресійної культури. Сучасні дослідники приділяли неабияке значення вивченню проблеми профресійної культури, розкриттю ії сутності й структури. Однак, як засвідчують результати їхніх досліджень, єдиного тлумачення наукового френомена «профресійна культура» не існує.

Так, аналіз довідкової літератури (словники, довідники, енциклопедії) указує на те, що поняття «профресійна культура» в більшості з них відсутнє. У більшості $€$ тлумачення понять «професійна підготовка», «професійна освіта» тощо. Лише в Українському педагогічному словнику за редакцією С. Гончаренка звертається увага на те, що культуру можна розглядати як рівень освіченості чи виховання людини, а також як рівень оволодіння певною галуззю знань [5, с. 182].

Дослідник С. Дружилов, вивчаючи питання професійної культури, доходить висновку, що це культура профресійного співтовариства чи представника певної профресії, яка, по-перше, охоплює способи організації професійної діяльності, що включають професійні цінності, норми, переконання, а по-друге, є результатом професійної самоідентифрікації [1, с. 5].

Учена А. Капська визначає профресійну культуру фрахівця як сукупність знань, умінь, навичок у поєднанні з особистісними якостями [3].

Дослідниця Ю. Чернова, розкриваючи сутність професійної культури фрахівця, указує на її інтегративний характер, що проявляється в культурі особистості й культурі діяльності [6, с. 57].

Цікавим $є$ підхід до розуміння сутності профресійної культури вченого Л. Когана, який уважає, що це поняття прямо пропорційне накопиченню професійного досвіду фахівця, який передбачає фрормування та удосконалення системи професійних знань і вмінь, що фрормує професійну зрілість.

На нашу думку, заслуговує на увагу тлумачення професійної культури вченою С. Ісаєнко, яка вважає, що вона є цілісним особистісним утворенням, сутність якого проявляється через діалектичний зв'язок усіх її елементів з погляду аксіологічного, діяльнісного та особистісного підходів [2, с. 28].

Профресійну культуру майбутніх фрізичних терапевтів та ерготерапевтів доцільно розглядати ієрархічно як похідну наукових френоменів «культура», «культура особистості», «професійна культура».

Не менш важливим, на нашу думку, під час розгляду професійної культури майбутніх фрахівців 3 фрізичної терапії та ерготерапії $€$ необхідність і доцільність співвіднесення ії із системою фрахових компетенцій, що визначені Стандартом підготовки здобувачів вищої освіти зі спеціальності 227 «Фізична терапія та ерготерапія» [4], а також із професійно значущими якостями, що мають бути сорормовані в такого фрахівця.

Так, з урахуванням теоретичного аналізу під профресійною культурою майбутніх фрізичних терапевтів та ерготерапевтів розумітимемо інтегровану характеристику особистості фрахівця, що синтезує його професійні мотиви й цінності, систему фрахових компетентностей (знань, умінь, навичок), професійно значущих якостей, які дають змогу здійснювати професійну діяльність на високому рівні реалізації фрахових фуункцій на основі рефрлексії та саморозвитку.

На основі структурно-змістового аналізу нами розглянуто структурні компоненти профресійної культури майбутнього фрахівця з фрізичної терапії та ерготерапії.

До компонентів зараховано ціннісно-мотиваційний, когнітивно-діяльнісний, особистісний та оцінювально-рефлексивний. Кожен із компонентів має свої елементи і зміст.

Так, ціннісно-мотиваційний компонент включає таке: 
- мотиви студентів до оволодіння продесійною культурою для виконання професійної діяльності на якісному рівні;

- спрямованість на майбутню професію з усвідомленням її значимості для профрілактики та збереження здоров'я людини;

- загальнолюдські та професійні цінності студентів як майбутніх фахівців, що визначають поведінку фрахівця в профресії.

Когнітивно-діяльнісний компонент охоплює систему фрахових знань і вмінь, що необхідні для реалізації профресійних фрункцій, які фрормуються в процесі теоретичної та практичної підготовки студентів через використання різних технологій, орорм, методів навчання.

Особистісний компонент передбачає наявність професійно значущих якостей як фрахівця, таких як цілеспрямованість, системність, комунікативність, емпатія, чуйність, толерантність, наполегливість, організованість тощо.

Рефрлексивний компонент включає здатність до оцінювання професійної діяльності інших і самооцінювання якості й рівня власної профресійної діяльності з орієнтацією на саморозвиток для профресійно-особистісного самовдосконалення.

Між компонентами професійної культури майбутніх фрізичних терапевтів та ерготерапевтів існує тісний взаємозв'язок, що вимагає одночасної їх сорормованості для ефективної реалізації професійної діяльності.

На нашу думку, наявність профресійної спрямованості й мотивів до оволодіння професією прямо впливає на активність студентів у засвоєнні системою фрахових компетентностей, а сформованість професійно значущих якостей - на якість реалізації профресійних умінь на практиці. Разом із тим здатність вивчати й оцінювати професійну діяльність фрізичних терапевтів-практиків і самооцінювати власну діяльність дасть змогу майбутнім фахівцям не лише професійно вдосконалюватися в процесі навчання в університеті, а й відчувати потребу означеного процесу під час роботи в закладах охорони здоров'я.

Формування професійної культури майбутніх фрізичних терапевтів та ерготерапевтів у процесі фахової підготовки вимагає створення визначених педагогічних умов, які мають бути спрямовані на вдосконалення змісту, фрорм, методів профресійної освіти, створення сприятливого освітнього середовища у процесі як теоретичного, так практичного навчання студентів.

Висновки. Отже, теоретичний і структурнозмістовий аналіз дає можливість стверджувати, що профресійна культура майбутніх фрахівців 3 фрізичної терапії та ерготерапії $€$ базовою умовою готовності їх до виконання професійних функцій у практичній діяльності. Професійна культура $€$ інтегрованою характеристикою фрахівця як особистості та як профресіонала.

До структури профресійної культури фрізичних терапевтів та ерготерапевтів входять особистісні (мотиви, спрямованість, цінності, професійно значущі якості) й діяльнісні (профресійні знання, уміння, навички, здатність до рефлексії) компоненти.

Означена публікація не вичерпує проблему дослідження. Подальшого вивчення потребують питання зарубіжного досвіду фрормування профресійної культури майбутніх фрізичних терапевтів та ерготерапевтів; педагогічних умов для ефективної фахової підготовки щодо формування професійної культури майбутніх фрізичних терапевтів; організації різних видів практики таких студентів.

\section{БІБЛІОГРАФІЧНИЙ СПИСОК:}

1. Дружилов С.А. Психологические проблемы профессионализма и профессиональной культуры специалиста. Новокузнецк : ИПК, 2000, 127 с.

2. Ісаєнко С.А. Формування профресійної культури у студентів : навчальний посібник. Київ, 2009. $120 \mathrm{c}$.

3. Капська А.Й. Соціальна робота : навчальнометодичний посібник. Київ : УДЦССМ, 2000, 220 с.

4. Стандарт вищої освіти за спеціальністю 227 «Фізична терапія, ерготерапія» для першого (бакалаврського) рівня вищої освіти (2018). URL: https://mon.gov.ua/storage/app/media/vishcha-osvita/ zatverdzeni\%20standarty /12/19/227-fizichna-terapiyaergoterapiya-bakalavr.pdf.

5. Український педагогічний словник / за ред. С.У. Гончаренка. Київ, 1997. 376 с.

6. Чернова Ю.К. Профрессиональная культура и формирование ее составляющих в процессе обучения. Москва, 2000, 230 с. 